\title{
ZINC AND CHROMIUM REMOVAL MECHANISMS FROM INDUSTRIAL WASTEWATER BY WATER HYACINTH, EICHHORNIA CRASSIPES (MART.) SOLMS
}

\author{
GAKWAVU, R.J. ${ }^{1}$ - SEKOMO, B.C. $.^{2,3}-$ NHAPI, I. ${ }^{1,2}$ \\ ${ }^{I}$ Department of Civil Engineering, Faculty of Applied Sciences, National University of Rwanda, \\ P.O. Box 117 Huye, Southern Province, Rwanda, \\ (phone: + (250) (0)788 523430$)$ \\ ${ }^{2}$ UNESCO-IHE Institute for Water Education, \\ P.O. Box 3015, Delft, the Netherlands \\ ${ }^{3}$ Department of Chemistry, Faculty of Sciences, National University of Rwanda, \\ P.O. Box. 117 Huye, Southern Province, Rwanda \\ *Corresponding author \\ e-mail: gakwavurjohn@yahoo.fr \\ (Received $1^{\text {st }}$ November 2009; accepted $10^{\text {th }}$ February 2012)
}

\begin{abstract}
Zinc and chromium are environmental pollutants that are toxic even at very low concentrations. Domestic and industrial wastewater discharges are probably the two most important sources for chromium and zinc in water. In Rwanda, the discharge into natural ecosystems of untreated wastewater containing heavy metals by factories and households is a growing problem. A bench-scale study was therefore conducted from May to October 2007 to investigate the major mechanisms responsible for $\mathrm{Cr}$ (VI) and $\mathrm{Zn}$ (II) removal from industrial wastewater using water hyacinth. The $\mathrm{pH}$ effects, plant relative growth, trace metal remaining in water samples, translocation ability, bioconcentration factor, adsorption, bioaccumulation and uptake mechanisms were investigated. The $\mathrm{pH}$ slightly increased from the start time $\mathrm{pH}=6.7(0 \mathrm{hr})$ to $\mathrm{pH}=7.64$ to $7.86(48 \mathrm{hr})$; but after 48 hours of experiment, the $\mathrm{pH}$ decreased due to the saturation of bond sites, resulting in some $\mathrm{H}+$ being released back into the water. The relative growth significantly decreased $(\mathrm{P} \leq 0.05)$ from 1,3 and $6 \mathrm{mg} / \mathrm{L}$ in 1 week but it slightly decreased linearly after 1 week with increasing metal concentrations $(\mathrm{P} \leq 0.05)$. About $56.7 \%$ of $\mathrm{Zn}$ (II) was accumulated in petioles, $27.0 \%$ in leaves and $16.3 \%$ in roots. For Cr (VI) $73.7 \%$ was taken up in roots, $14.1 \%$ in petioles and $12.2 \%$ in leaves. It was observed that $17.6 \%, 6.1 \%$ and $1.1 \%$ were adsorbed for 1,3 and 6 $\mathrm{mg} / \mathrm{L}$ of $\mathrm{Zn}$ (II) concentrations, respectively, by water hyacinth plants. For $\mathrm{Cr}(\mathrm{VI}), 9.0 \%, 36.4 \%$ and $54.6 \%$ were adsorbed for 1,3 and $6 \mathrm{mg} / \mathrm{L}$, respectively. The order of translocation ability for $\mathrm{Cr}(\mathrm{VI})$ was leaves $<$ petioles $<$ roots in water hyacinth whereas for $\mathrm{Zn}$ (II) it was leaves $<$ roots $<$ petioles.
\end{abstract}

Keywords: Adsorption experiments, chromium removal, industrial wastewater, metal removal mechanisms, water hyacinth, zinc removal

\section{Introduction}

Zinc and chromium are environmental pollutants that are toxic even at very low concentrations. The pollution of the biosphere with toxic metals has accelerated dramatically since the beginning of the industrial revolution (Nriogo, 1979). The primary sources of this pollution include the burning of fossil fuels, mining and smelting of metals, municipal wastes, fertilizers, pesticides and sewage. Heavy metals are of great concern primarily due to their known toxicity to aquatic life and human health at trace levels (Lesage, 2000). It has been reported that domestic and industrial discharges are probably the two most important anthropogenic sources of metals in aquatic systems (Stephenson et al., 1980). However, the lack of a reliable method to 
predict metals distribution in treatment units is a key weakness in determining the fate of metals and their transportation in wastewater treatment processes, and therefore the development of effective pre-treatment guidelines (Memon, 2000). The removal of heavy metals from aqueous solutions has therefore received considerable attention in recent years. However, the practical application of physicochemical technology such as chemical precipitation, membrane filtration and ion exchange is sometimes restricted due to technical or economical constraints. For example, the ion exchange process is very effective but requires expensive adsorbent materials (Lehmann et al., 1999; Volesky, 2001).

The use of low-cost waste materials as adsorbents of dissolved metal ions provides economically viable solutions to this global problem and could be considered an ecofriendly solution (Volesky and Holan, 1995; Mullen et al., 1989). At present, emphasis is given to the utilization of biological adsorbants for the removal and recovery of heavy metal contaminants (Mullen et al., 1989). A research study was therefore conducted in Rwanda, where there are no appropriate systems of heavy metals removal, particularly for zinc and chromium which are some of the main contaminants released from textile and other industries. The development of a system to remove these toxic contaminants was investigated using a pilot scale bench study and conducted from May to October 2007. The aim was to investigate the major mechanisms responsible for $\mathrm{Cr}$ (VI) and $\mathrm{Zn}$ (II) removal from industrial wastewater using water hyacinth. The water hyacinth plant is rapidly infesting many aquatic ecosystems in the country. However, there are possibilities for using the hyacinth plant in heavy metal removal, considering its reported successes in general wastewater treatment (Mullen et al., 1989). Such a system could be inexpensive, providing Rwanda and other developing countries with an appropriate technology thus contributing to environmental sustainability.

\section{Materials and methods}

\section{Water hyacinth collection and preparation}

The pilot-scale experiments were performed using free-floating water hyacinth $(E$. Crassipes) plants that had been collected from a natural wetland area called Nyabugogo located in Kigali City. The plants were transported to the Chemistry Laboratory of the National University of Rwanda, Butare, in big plastic buckets as shown in Fig. 1(a). They were then placed under natural sunlight for several days to let them adapt to the new environment in the laboratory. The plants with similar size, weight and shape were selected, rinsed with distilled water to remove any epiphytes and insect larvae grown on plants and then placed in small buckets for experiments as shown in Fig. 1(b).

(a)

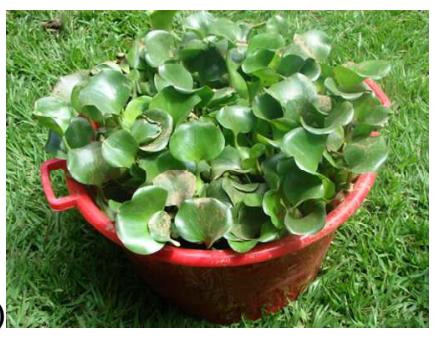

(b)

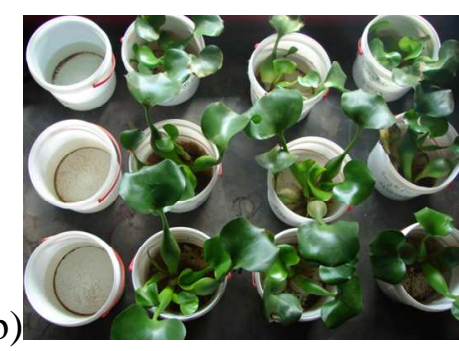

Figure 1. Water hyacinth collection and preparation (a) plants in big container, (b) plan view of experimental set up 
All experiments were run in batch mode, using a nutrient solution containing $500 \mathrm{ml}$ of tap water from the valley located at Butare near the Natural Science Centre, $500 \mathrm{ml}$ of wastewater from the Nyabugogo wetland and $20 \mathrm{mg}$ of $\mathrm{Ca}\left(\mathrm{NO}_{3}\right)_{2} .4 \mathrm{H}_{2} \mathrm{O}$ and $\mathrm{NH}_{4} \mathrm{Cl}$, and $40 \mathrm{mg}$ of $\mathrm{K}_{2} \mathrm{HPO}_{4}$. The total fresh weight of plants in each bucket was measured before the start of each growing time, which was 1, 2 and 4 weeks.

\section{Description of the experimental setup in the laboratory}

The laboratory experimental setup for zinc and chromium removal mechanisms consisted of 12 small buckets as show in Fig 1(b). The three buckets without water hyacinth plants served as controls (blanks) containing 1,3 and $6 \mathrm{mg} / \mathrm{L}$ of zinc and chromium. Nine (9) small buckets with water hyacinth plants were used with 3 buckets each containing 1,3 and $6 \mathrm{mg} / \mathrm{L}$ of zinc and chromium. The buckets were maintained for 1, 2 and 4 weeks which were the experimental periods. All experiments were performed in the laboratory at a constant temperature $\left(25^{\circ} \mathrm{C}\right)$. A stock solution $(1,000 \mathrm{mg} / \mathrm{L})$ of each metal was prepared in distilled water which was later used as dilution water. Individual plants were initially rinsed with distilled water to remove epiphytes, microbes, and any nutrient that might be transferred and were then placed in $2 \mathrm{~L}$ small plastic buckets containing $1 \mathrm{~L}$ of solution $(0.5 \mathrm{~L}$ from Nyabugogo wetland $+0.5 \mathrm{~L}$ from Butare valley ). The plants were maintained in water supplemented by the heavy metals by adding the required volume of zinc and chromium stock solutions to obtain final concentrations of 1,3 and $6 \mathrm{mg} / \mathrm{L}$ of $\mathrm{Cr}\left(\mathrm{K}_{2} \mathrm{CrO}_{4}\right)$ and $\mathrm{Zn}\left(\mathrm{ZnCl}_{2}\right)$, respectively.

Distilled water was added in order to compensate for water losses through plant transpiration, sampling and evaporation. Water samples and $\mathrm{pH}$ measurements were taken every 60 minutes for the first 6 hours and then one sample per day during 1, 2 and 4 weeks of exposure to the metal solution. All samples were filtered using $0.45 \mu \mathrm{m}$ cellulose acetate filters (Whatman papers) and acidified with 5 drops of nitric acid prior to the storage of samples. The samples were then analyzed using a Perkin Elmer Atomic Absorption Spectrometer. After each test duration (1,2 and 4 weeks), the final fresh weight for each water hyacinth plant was taken and the plants were harvested for other analyses. They were separated into petioles, roots and leaves and analyzed for relative growth, metals accumulation, translocation ability, bioconcentration factor (BCF) and adsorption on the outer surface of roots. In addition, the metals remaining in the solution were measured to assess the removal capacity of the water hyacinth plants.

\section{Data analyses}

\section{a) Relative Growth ( $R G)$}

The relative growth of control and treated plants was calculated using Equation 1 to assess the effects of zinc and chromium concentrations on water hyacinth plant growth.

$$
\mathrm{RG}=\mathrm{FFW} / \mathrm{IFW}
$$

Where $R G$ denotes relative growth of water hyacinth plants during experimental period, dimensionless;

$F F W$ denotes final fresh weight in grams of water hyacinth plants taken at the end of each experimental period, and

IFW denotes the initial fresh weight in grams of water hyacinth plants taken before starting experiment. 


\section{b) Bioconcentration Factor (BCF)}

The BCF provides an index of the ability of the plant to accumulate the metal with respect to the metal concentration in the substrate. The BCF was calculated using Equation 2. A larger ratio implies better phytoaccumulation capability.

$$
\mathrm{BCF}=(\mathrm{P} / \mathrm{E})_{i} .
$$

Where $\boldsymbol{i}$ denotes the heavy metal concerned,

$\boldsymbol{B C F}$ is the dimensionless bioconcentration factor,

$\boldsymbol{P}$ represents the trace element concentration in plant tissues $\left(\mathrm{mgL}^{-1}\right)$,

$\boldsymbol{E}$ represents the initial concentration in water $(\mathrm{mg} / \mathrm{L})$ or in the sediment $(\mathrm{mg} / \mathrm{kg}$ dry wt).

\section{c) Metal Accumulation}

Metals accumulation in plant and water samples were measured. Digestion of samples in this study was performed according to the Standard Methods (APHA/AWWA/WEF, 2005). Plant biomass samples were reduced to dry matter by heating at $105^{\circ} \mathrm{C}$ for 24 hours in a hot air oven and the ash was digested with nitric acid $\left(\mathrm{HNO}_{3}\right)$ and hydrogen peroxide $\left(\mathrm{H}_{2} \mathrm{O}_{2}\right)$, filtered through a Whatman ${ }^{\circledR}$ filter paper into a volumetric flask before Atomic Absorption Spectrometer analyses. The following three mechanisms were investigated to differentiate the metal adsorption, bioaccumulation, and translocation by water hyacinth during the experimental period.

\section{Adsorption}

The adsorption consists of metal attachment to the outer surface of the plant. Adsorption was quantified after the plant had been exposed to different concentrations of chromium and zinc in different periods of times (1week, 2 weeks and 4 weeks). At the end of the experiment, adsorption was determined by placing roots of the water hyacinth plant in nine $100 \mathrm{ml}$ of EDTA-Na 3,24 mmolar respectively for 5, 10, 15, 20, $25,30,35,40$ and 45 minutes. This was to remove zinc and chromium trace elements on the outer surface of the roots. The EDTA-NA 2 solutions were then filtered, acidified by 5 drops of nitric acid $\left(\mathrm{HNO}_{3}\right)$, and then analyzed by Atomic Absorption Spectrometer (AAS) to determine the zinc and chromium adsorbed by the plants. The most important parameter to consider is the $\mathrm{pH}$ (Keith et al., 2006). Generally when the $\mathrm{pH}$ decreases, the toxicity of metal ions increases because the proportion of the adsorbed ion on the root system decreases (Kara, 2005).

\section{Uptake}

The uptake process is a mechanism by which metal ions are transported across the cell membrane and can be used in the building of new biomass or stored in vacuoles. This mechanism was assessed at the end of the experimental period when water hyacinth plants were taken out from the small buckets and roots, petioles and leaves were separated, dried in an oven at $105^{\circ} \mathrm{C}$ for 24 hours. The plant samples were transformed into ash, digested and analyzed by AAS to determine the zinc and chromium concentrations in plant biomass (roots, leaves and petioles). The results from 
AAS analyses show the plant parts which have higher metal accumulations. The presence of carboxyl groups at the roots system induces a significant cation exchange capacity and this could be the mechanism of moving heavy metal in the roots system where active absorption takes place.

\section{Translocation ability (TA)}

The translocation ability was calculated by dividing the concentration of a trace element accumulated in the root tissues by that accumulated in shoot tissues (Volesky and Holan, 1995). TA was calculated using Equation 5.

$$
T A=(A r / A s)_{i}
$$

Where $i$ denotes the heavy metal concerned,

$\boldsymbol{T A}$ is the translocation ability and is dimensionless,

Ar represents the amount of trace element accumulated in the roots $\left(\mathrm{mgL}^{-1} \mathrm{dw}\right)$, and

As represents the amount of trace element accumulated in the shoots $\left(\mathrm{mgL}^{-1} \mathrm{dw}\right)$

\section{Statistical analysis}

In order to detect quantitative differences in the data, statistical analyses were performed.

Standard deviation

The standard deviation was obtained from the variance by extracting the square root and was expressed in the unit in which the measurements were taken:

$$
\mathrm{S}=\sqrt{\frac{\sum f d^{2}}{(n-1)}}
$$

Regression analysis

Regression is defined as the determination of statistical relationship between two or more variables. In simple regression one variable (defined as independent) is the cause of the behaviour of another one (defined as dependent variable). The correlation coefficient ( $r$ ) is expressed by equation:

$$
\mathrm{r}=\frac{\sum d x \cdot d y}{\sqrt{\sum d x^{2} \cdot \sum d y^{2}}}
$$

\section{Results and discussions}

\section{Effects of $p H$ variations}

The initial solution $\mathrm{pH}$ was adjusted to 6.7 in the small plastic buckets using $\mathrm{HCl}$ or $\mathrm{NaOH}$. This is the $\mathrm{pH}$ tested in Nyabugogo Wetland from where the hyacinth was collected. The $\mathrm{pH}$ variations over time for the water hyacinth-covered containers are 
shown in Figure 3. The $\mathrm{pH}$ varied considerably in different buckets with water hyacinth plants over the exposure time.

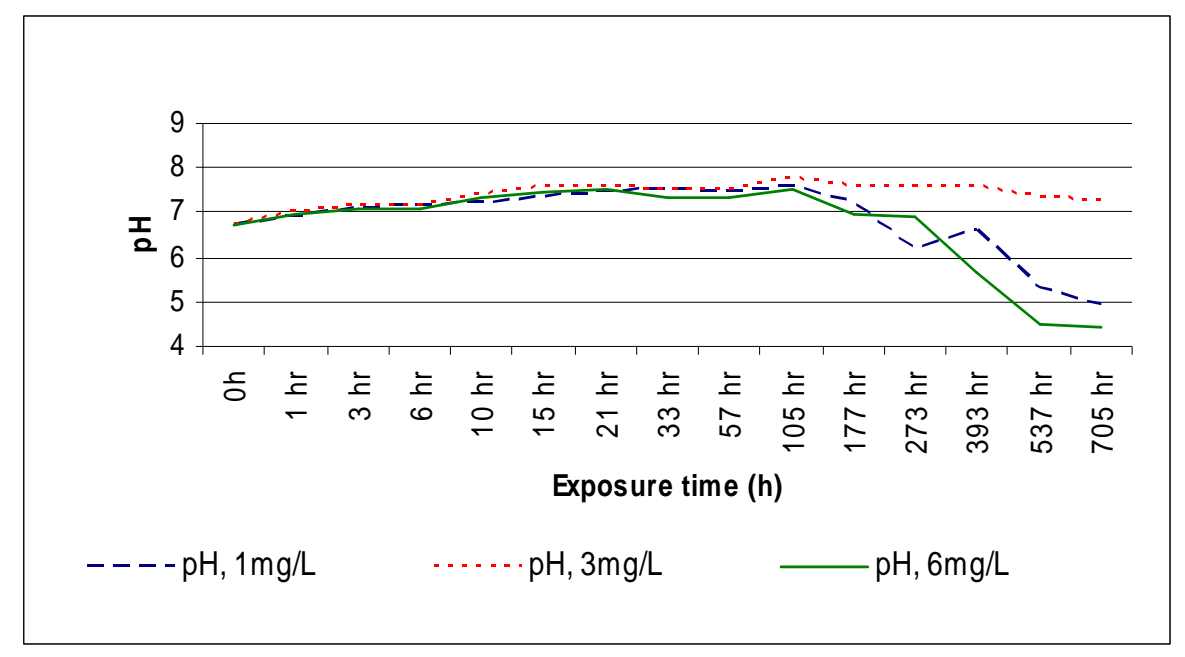

Figure 2. Results for $p H$ variations in water hyacinth covered containers

Metals will precipitate as hydroxides when the $\mathrm{pH}$ of the wastewater is raised to $\mathrm{pH} 8$ to 11 (Barron et al., 1982). As a result, the extent of adsorption was rather low at low $\mathrm{pH}$ values. However, in the equilibrium solid phase, $\mathrm{Zn}$ (II) and $\mathrm{Cr}$ (VI) ion concentrations increased with increasing $\mathrm{pH}$ because of increasingly negative charges on the surfaces of the roots at high $\mathrm{pH}$ values. This attracted positively charged $\mathrm{Zn}$ (II) and $\mathrm{Cr}$ (VI) ions more strongly. The ANOVA with replications showed that for $1 \mathrm{mg} / \mathrm{L}$, $3 \mathrm{mg} / \mathrm{L}$ and $6 \mathrm{mg} / \mathrm{L}$ there was no effect of exposure time but high difference between $\mathrm{pH}$ effects and metal remaining in water samples $(\mathrm{P} \leq 0.05)$. It was observed that the $\mathrm{pH}$ effect variations were due to the saturation of binding sites on root systems which affect the $\mathrm{pH}$ in water samples with water hyacinth plants by releasing $\mathrm{H}+$ in water samples.

\section{Plant relative growth $(R G)$}

The relative growth of water hyacinth plants at different concentrations of zinc and chromium is shown in Table 1. It can be seen that the relative growth of plants decreases with the increase of zinc and chromium concentrations.

Table 1. Relative changes in growth of plants vs. zinc and chromium concentrations

\begin{tabular}{c|c|c|c}
\hline $\begin{array}{c}\text { Exposure time (week) with Zn } \\
\text { \& Cr concentrations }\end{array}$ & $\begin{array}{c}\text { Initial water } \\
\text { hyacinth fresh } \\
\text { weight (g) }\end{array}$ & $\begin{array}{c}\text { Final water } \\
\text { hyacinth fresh } \\
\text { weight }(\mathbf{g})\end{array}$ & $\begin{array}{c}\text { Relative } \\
\text { growth }\end{array}$ \\
\hline $1 \mathrm{wk}, 1 \mathrm{mg} / \mathrm{L}$ & 32.33 & 85.23 & 2.64 \\
$1 \mathrm{wk}, 3 \mathrm{mg} / \mathrm{L}$ & 34.50 & 96.91 & 2.81 \\
$1 \mathrm{wk}, 6 \mathrm{mg} / \mathrm{L}$ & 26.38 & 50.07 & 1.89 \\
$2 \mathrm{wks}, 1 \mathrm{mg} / \mathrm{L}$ & 29.75 & 55.92 & 1.88 \\
$2 \mathrm{wks}, 3 \mathrm{mg} / \mathrm{L}$ & 42.90 & 80.18 & 1.87 \\
$2 \mathrm{wks}, 6 \mathrm{mg} / \mathrm{L}$ & 16.24 & 39.96 & 2.27 \\
$4 \mathrm{wks}, 1 \mathrm{mg} / \mathrm{L}$ & 41.15 & 85.57 & 2.08 \\
$4 \mathrm{wks}, 3 \mathrm{mg} / \mathrm{L}$ & 39.65 & 98.05 & 2.47 \\
$4 \mathrm{wks}, 6 \mathrm{mg} / \mathrm{L}$ & 34.54 & 96.16 & 2.78 \\
\hline
\end{tabular}


For water hyacinth plants treated with $\mathrm{Zn}$ and $\mathrm{Cr}$, the plant relative growth significantly decreased $(\mathrm{P} \leq 0.05)$ from 1,3 and $6 \mathrm{mg} / \mathrm{L}$ in 1 week but for 2 and 4 weeks, the relative growth decreased only slightly with increasing $(\mathrm{P} \leq 0.05)$ metal concentrations. The relative growth exhibited a decreasing trend caused by relative increases in toxicity of chromium and zinc. The analysis of variance showed that for 1 week exposure time, there is a high effect (difference is significant) of initial concentrations $(1,3$ and $6 \mathrm{mg} / \mathrm{L})$ to the growth of the plants $(\mathrm{P}>0.05)$, but for 2 and 4 weeks related to initial concentrations, the difference is not significant $(\mathrm{P}>0.05)$. Xiaomei et al. (2004) reported that the relative growth of water hyacinth decreases when metal concentrations increase, confirming what was observed in this investigation.

\section{Bioconcentration Factor (BCF) of zinc and chromium}

The bioconcentration factor $(\mathrm{BCF})$ was calculated as the ratio of the trace element concentration in the plant tissues at harvest to the concentration of the element in the external environment (Zayed, 1998). The pattern of the bioconcentration factor of water hyacinth plants is shown in Fig. 3.

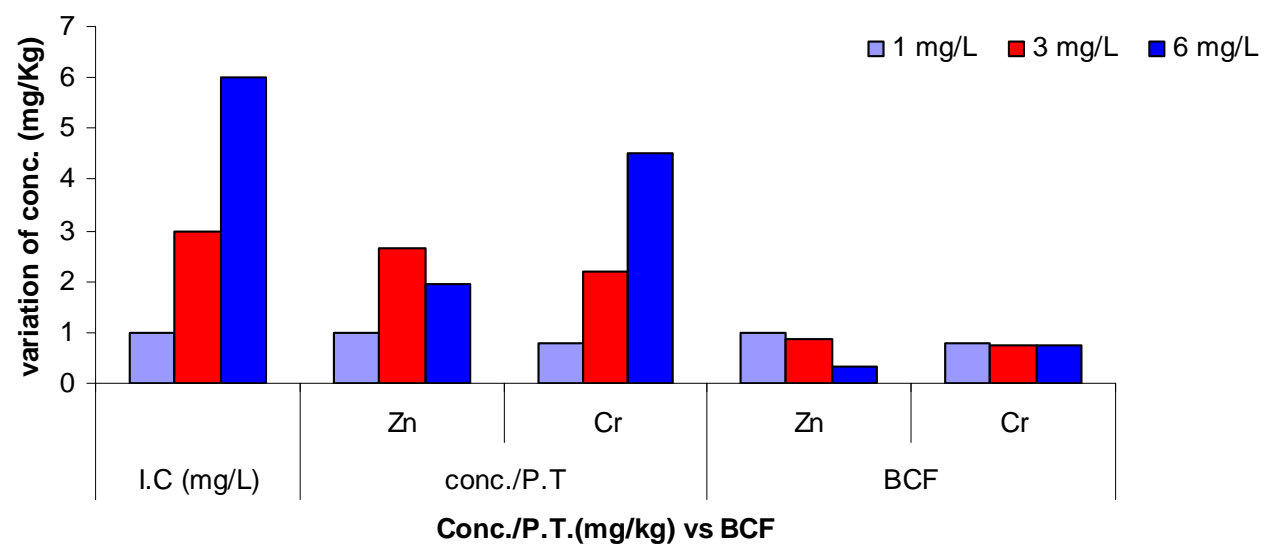

Note: I.C.: initial concentrations (mg/L); Conc./P.T: concentration in plant tissues (mg/Kg); BCF: Bioconcentration Factor.

Figure 3. BCF for different initial concentrations of Zinc and Chromium

A high competition between zinc and chromium accumulation by the plants was observed due to the kinetics of these metals. The comparison of $\mathrm{Zn}$ (II) and $\mathrm{Cr}$ (VI) showed that the BCF of zinc was higher than the chromium's BCF for 1 and $3 \mathrm{mg} / \mathrm{L}$, but very low for $6 \mathrm{mg} / \mathrm{L}$ for zinc. The plant accumulated more for low initial concentrations than for high ones. It was observed that there is no significant difference both for zinc and chromium when comparing initial concentrations to the concentrations in plant tissues and bioconcentration factors for zinc and chromium $(\mathrm{P}>0.05)$.

\section{Adsorption}

Figure 4 shows the adsorption experimental results for zinc and chromium. The removal was highest for the first 15 minutes and the highest chromium concentrations observed for $6 \mathrm{mg} / \mathrm{L}$ was around $2 \mathrm{mg} / \mathrm{L}$, for $3 \mathrm{mg} / \mathrm{L}$ was around $1.6 \mathrm{mg} / \mathrm{L}$ and for 1 $\mathrm{mg} / \mathrm{L}$ was around $0.3 \mathrm{mg} / \mathrm{L}$. The adsorption capacity of water hyacinth plants seemed to be different when zinc and chromium are compared. For zinc, $17.6 \%$ of $1 \mathrm{mg} / \mathrm{L}$ was 
adsorbed by the water hyacinth plants, $6.1 \%$ of $3 \mathrm{mg} / \mathrm{L}$ was adsorbed and the plants adsorbed $1.1 \%$ of $6 \mathrm{mg} / \mathrm{L}$. For chromium, $9.0 \%$ of $1 \mathrm{mg} / \mathrm{L}, 36.4 \%$ of $3 \mathrm{mg} / \mathrm{L}$ and 54.6 $\%$ of $6 \mathrm{mg} / \mathrm{L}$ were adsorbed by the water hyacinth plants. Meggo(2001) has confirmed that aquatic plants are able to accumulate metals at low concentrations.

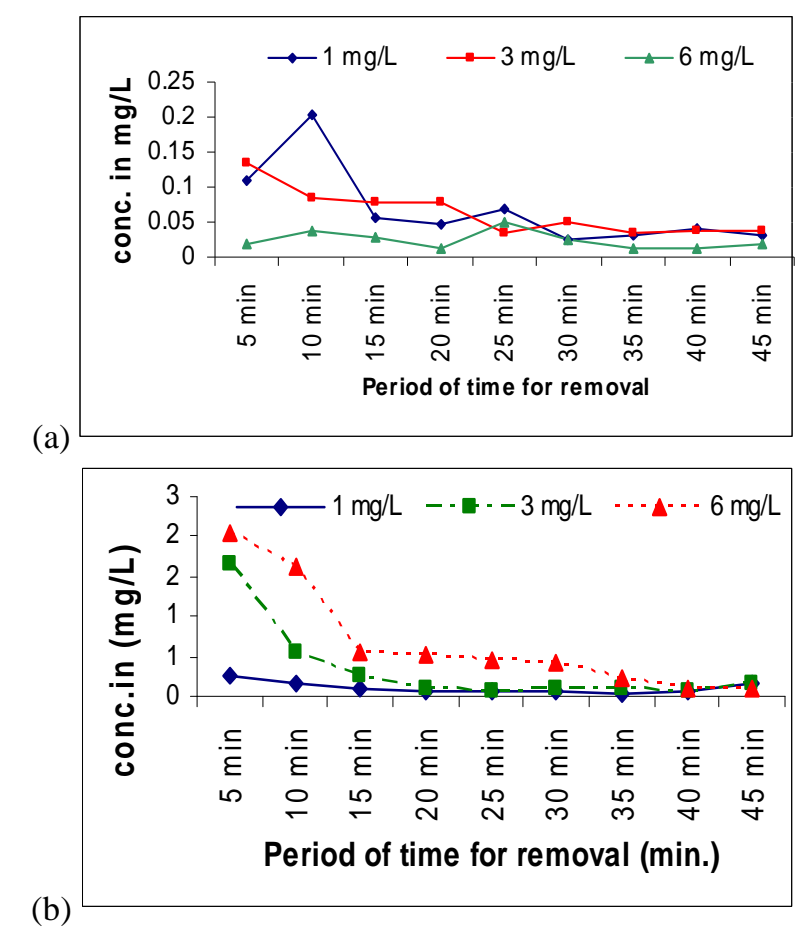

Figure 4. Desorption over time for various initial concentrations of (a) and (b) chromium

\section{Uptake for zinc and chromium}

It was observed that $56.7 \%$ of zinc was accumulated in petioles, $27.0 \%$ in leaves and $16.3 \%$ in roots. The analysis demonstrated no significant difference for different initial concentration and exposure time $(p>0.05)$ in uptake mechanisms of zinc. There was a significant difference observed in plant parts in uptake processes $(p \leq 0.05)$. For chromium, $73.7 \%$ was taken up in roots, $14.1 \%$ in petioles and $12.2 \%$ in leaves, demonstrating the preference of plants to store chromium in roots. The trend was the same for zinc; no significant difference existed between plant parts $(\mathrm{p}>0.05)$ and also between initial concentrations in uptake processes $(p>0.05)$.

\section{Translocation ability (TA)}

The quantities of trace elements accumulated in the petioles exceeded those in the shoots. Roots of water hyacinth accumulated about 3 to 15 times more trace elements than did the shoots. It appears that chromium translocation is comparable to zinc as shown in Table 2. The ability of plants to translocate trace elements of chromium increased for roots/leaves $(5.3$ times for $1 \mathrm{mg} / \mathrm{L}, 6.5$ times for $3 \mathrm{mg} / \mathrm{L}$ and 6 times for 6 $\mathrm{mg} / \mathrm{L}$ ). The number of times for roots/petioles decreases ( 4 times for $1 \mathrm{mg} / \mathrm{L}, 4$ times for $3 \mathrm{mg} / \mathrm{L}$ and 7 times for $6 \mathrm{mg} / \mathrm{L}$ ) because the order of storage was leaves $<$ petioles $<$ roots. 
Table 2. TA of (a) zinc and (b) chromium

\begin{tabular}{|c|c|c|c|c|}
\hline \multicolumn{5}{|c|}{ (a) Initial conc. of $\mathrm{Zn}(\mathrm{II})$} \\
\hline & Roots/ Shoots & $1 \mathrm{mg} / \mathrm{L}$ & $3 \mathrm{mg} / \mathrm{L}$ & $6 \mathrm{mg} / \mathrm{L}$ \\
\hline 1 week & $\begin{array}{l}\text { Roots/petioles } \\
\text { Roots/leaves }\end{array}$ & $\begin{array}{l}0.382^{\mathrm{a}} \\
1.114^{\mathrm{a}}\end{array}$ & $\begin{array}{l}0.255^{\mathrm{a}} \\
0.732^{\mathrm{a}}\end{array}$ & $\begin{array}{l}0.383^{\mathrm{a}} \\
0.164^{\mathrm{a}}\end{array}$ \\
\hline 2 weeks & $\begin{array}{l}\text { Roots/petioles } \\
\text { Roots/leaves }\end{array}$ & $\begin{array}{l}0.478^{\mathrm{a}} \\
0.461^{\mathrm{a}}\end{array}$ & $\begin{array}{l}0.485^{\mathrm{a}} \\
0.564^{\mathrm{a}}\end{array}$ & $\begin{array}{l}0.439^{\mathrm{a}} \\
0.993^{\mathrm{a}}\end{array}$ \\
\hline 4 weeks & $\begin{array}{c}\text { Roots/petioles } \\
\text { Roots/leaves }\end{array}$ & $\begin{array}{l}0.171^{\mathrm{a}} \\
0.241^{\mathrm{a}} \\
\end{array}$ & $\begin{array}{l}0.510^{\mathrm{a}} \\
1.041^{\mathrm{a}} \\
\end{array}$ & $\begin{array}{l}0.109^{\mathrm{a}} \\
0.255^{\mathrm{a}} \\
\end{array}$ \\
\hline & (b) $I n$ & conc. of & & \\
\hline & Roots/ Shoots & $1 \mathrm{mg} / \mathrm{L}$ & $3 \mathrm{mg} / \mathrm{L}$ & $6 \mathrm{mg} / \mathrm{L}$ \\
\hline 1 week & $\begin{array}{c}\text { roots/petioles } \\
\text { roots/leaves }\end{array}$ & $\begin{array}{l}4.104 a \\
5.288 a\end{array}$ & $\begin{array}{l}3.663 a \\
6.487 a\end{array}$ & $\begin{array}{l}6.831 \mathrm{a} \\
5.965 \mathrm{a}\end{array}$ \\
\hline 2 weeks & $\begin{array}{c}\text { Roots/petioles } \\
\text { Roots/leaves }\end{array}$ & $\begin{array}{l}2.012 \mathrm{a} \\
2.365 \mathrm{a}\end{array}$ & $\begin{array}{l}2.254 \mathrm{a} \\
3.851 \mathrm{a}\end{array}$ & $\begin{array}{l}5.870 \mathrm{a} \\
4.564 \mathrm{a}\end{array}$ \\
\hline 4 weeks & $\begin{array}{c}\text { Roots/petioles } \\
\text { Roots/leaves }\end{array}$ & $\begin{array}{l}1.235 \mathrm{a} \\
2.578 \mathrm{a}\end{array}$ & $\begin{array}{l}3.258 \mathrm{a} \\
3.851 \mathrm{a}\end{array}$ & $\begin{array}{l}1.239 \mathrm{a} \\
1.008 \mathrm{a}\end{array}$ \\
\hline
\end{tabular}

An ANOVA was performed on the variability in translocation ability. It was observed that the difference between metal concentrations is not significant $(p>0.05)$ and there was no significant difference between roots and shoots translocation ( $p>$ 0.05). Stratford et al. (1984) found that metal accumulations in water hyacinth increased linearly with solution metal concentration in order leaves<petioles<roots. In this research, the following order was observed: leaves<roots<petioles. When the concentration is high, the water hyacinth plant can only accumulate a low concentration in plant cells. This is in agreement with the results of this study in the case of chromium concentration accumulation in water hyacinth plants, where the high concentration was accumulated in roots followed by petioles and then leaves. Water hyacinth materials were burned after all experiences to avoid the contamination.

\section{Conclusions and recommendations}

From the above results, it is concluded that water hyacinth could effectively remove zinc and chromium from industrial wastewater. The removal mechanisms of zinc and chromium by water hyacinth plants showed that the plant concentrated a high quantity of metals. The experiments conducted under this study could be up-scaled to include treatment of actual wastewater from various industries. Essential design parameters such as hydraulic retention time needs to be determined so that the technology can be widely used in Rwanda and beyond.

Acknowledgements. The authors are very grateful to Nuffic for sponsoring this study through the WREM Project, a collaborative capacity building project between the National University of Rwanda and the UNESCO-IHE Institute for Water Education. 


\section{REFERENCES}

[1] APHA/AWWA/WEF (2005): Standard methods for the examination of water and wastewater. - APHA, 21st edition, Washington, DC. 2001-3710.

[2] Barron, L., Weand, J.J.F., Benefield, L.D. (1982): Process chemistry for water and wastewater treatment. - Prentice-hall international, Inc, London.

[3] Kara, Y. (2005): Bioaccumulation of $\mathrm{Cu}, \mathrm{Zn}$ and $\mathrm{Ni}$ from wastewater by treated Nasturtium officinale. - Department of Biology, Faculty of science and Art, China.

[4] Keith, C., Borazjanim H.S., Diehl, V.Y., Baldwin, B.S. (2006): Removal of Copper, Chromium, and Arsenic by Water Hyacinths. - Forest Products Department, Forest and Wildlife Research Center, Mississippi State University, MS.

[5] Lehmann, M., Zouboulism A.I., Matis, K.A. (1999): Removal of metal ions from dilute aqueous solutions: a comparative study of inorganic sorbent materials. - Chemosphere 39: 881-892.

[6] Lesage, E. (2006): Behaviour of heavy metals in constructed treatment wetlands. - PhD thesis, Faculty of Bioscience Engineering, Ghent University, Ghent, Belgium, 247 pp.

[7] Meggo, R. (2001): Allocation pattern of Lead and Zinc in Cyperus papyrus and Lemna gibba. - MSc Thesis, DEW 147 DELFT IHE, Netherlands, pp 44.

[8] Memon, A.R. (2000): Heavy Metal Accumulation and Detoxification Mechanisms in Plants. - Marmara Research Center, Institute for Genetic Engineering and Biotechnology, USA.

[9] Mullen, M.D., Wolf, D.C., Ferris, F.G., Beveridge, T.J., Flemming, C.A., Bailey, G.W. (1989): Bacterial sorption of heavy metals. - Appl. Environ. Microbiol. 55: 3143-3149.

[10] Nriogo, J.O. (1979): Global inventory of natural and anthropogenic emissions of trace metals to the atmosphere. - Nature 279: 409-411.

[11] Stephenson, M.G., Turner, P.P., Colt, J., Knight, A., Tchobanoglous, G. (1980): The Use and Potential of Aquatic Species for Wastewater Treatment. - Publication No. 65, California State Water Resources Control Board.

[12] Stratford, H.K., William, T.H., Leon, A. (1984): Effects of heavy metals on water hyacinths (Eichhornia crassipes). - Aquat Toxicol 5(2): 117-128.

[13] Volesky, B. (2001): Detoxification of metal-bearing effluents: biosorption for the next century. - Hy ódrometallurgy 59: 203-216.

[14] Volesky, B., Holanm, Z.R. (1995): Biosorption of heavy metals. - Biotechnol. Prog. 11: 235-250.

[15] Xiaomei, L., Maleeya, K., Prayad, P., Kunaporn, H. (2004): Removal of Cadmium and Zinc by Water Hyacinth, Eichhornia crassipes. - Department of Biology, Faculty of Life Science, Hubei University, Wuhan 430062, P. R. China.

[16] Zayed, A., Gowthaman, S., Terry, N. (1998): Phytoaccumulation of trace elements by wetland plants: I. Duck weed. - J. Environ. Qual. 27: 715-721. 